\title{
Summer heat stress and strain during outdoor running in Aotearoa New Zealand
}

\author{
Toby Mündel ${ }^{* *}$, Melissa Black¹, Nicole E Moyen ${ }^{1,2}$, Blake Perry ${ }^{1}$ \\ From 15th International Conference on Environmental Ergonomics (ICEE XV) \\ Portsmouth, UK. 28 June - 3 July 2015
}

\begin{abstract}
Introduction
A large body of work has identified the response to and consequence of exercise in a hot climate. However, typically this has been laboratory-based, which often misrepresents such a 'climate'. Those field studies conducted have often been based in the Northern Hemisphere during summer periods. Solar stress during a Southern Hemisphere summer, particularly New Zealand, is 10 \% greater for a given latitude in the Northern Hemisphere (or the combined effects of an equator-ward shift of $4^{\circ}$ in latitude and $1 \mathrm{~km}$ increase in altitude) due to i) greater irradiances due to a lesser Sun-Earth separation owing to the elliptical orbit of the Earth about the Sun, ii) lower ozone levels due to the lesser Sun-Earth separation, and iii) lower tropospheric pollution [1].

The purpose of this study was to measure heat exposure and strain from running outdoors in the New Zealand summer, in order to determine what factor(s) might predict performance and risk for heat illness.
\end{abstract}

\section{Methods}

Using an observational field study design, 10 male runners (age: $45 \pm 12 \mathrm{y}$, peak speed: $19 \pm 2 \mathrm{~km} \cdot \mathrm{h}^{-1}$ ) took part in a weekly $7 \mathrm{~km}$ race (start time 18:15 h) over six weeks (45 observations). Pertinent climatic measures were recorded including $\mathrm{T}_{\mathrm{db}}, \mathrm{T}_{\mathrm{wb}}$ and $\mathrm{T}_{\mathrm{bg}}$, and thus WBGT. Along with performance time, starting and end gastro-intestinal temperature $\left(\mathrm{T}_{\mathrm{gi}}\right)$, time-averaged arm temperature $\left(\mathrm{T}_{\mathrm{arm}}\right)$, and starting urine specific gravity were measured and a questionnaire asking about perception (thermal comfort, thermal sensation and exertion) and heat illness symptoms was administered following the race. Data were analysed using linear regression.

* Correspondence: t.mundel@massey.ac.nz

${ }^{1}$ School of Sport and Exercise, Massey University, New Zealand

Full list of author information is available at the end of the article

\section{Results}

Of the six weeks observed, two weeks measured a WBGT above $27^{\circ} \mathrm{C}$; for both these weeks $\mathrm{T}_{\mathrm{db}}$ remained below $26{ }^{\circ} \mathrm{C}$ and relative humidity below $60 \%\left(\mathrm{~T}_{\mathrm{wb}} \leq\right.$ $20{ }^{\circ} \mathrm{C}$ ) whilst $\mathrm{T}_{\text {bg }}$ measured 53 and $57{ }^{\circ} \mathrm{C}$, respectively. Urine specific gravity mostly (78\%) described participants as not being dehydrated when beginning the race (i.e. <1.020). An end- $\mathrm{T}_{\mathrm{gi}}>40{ }^{\circ} \mathrm{C}$ was observed on 10 occasions, however, few participants registered symptoms of heat illness and mean thermal sensation registered above "warm" only on three of the ten occasions and mean thermal comfort never registered above "uncomfortable." Linear regression identified perceived exertion and thermal comfort at the end of the race as strongest predictors of performance (model $R^{2}=0.50, p=$ $0.02), \mathrm{T}_{\mathrm{db}}$ and $\mathrm{T}_{\mathrm{wb}}$ as strongest predictors of end- $\mathrm{T}_{\text {core }}$ (model $R^{2}=0.38, p=0.09$ ), and performance time and starting $\mathrm{T}_{\mathrm{gi}}$ as strongest predictors of heat illness symptoms (model $R^{2}=0.30, p=0.37$ ).

\section{Discussion}

Based on the WBGT during the race, the most recent ACSM guidelines [2] would classify this climate as high risk for unfit, unacclimatized individuals; this is despite relatively low $T_{d b}$ and $T_{w b}$ values, and highlights the increased role that solar radiation $\left(\mathrm{T}_{\mathrm{bg}}\right)$ plays to summer heat exposure in New Zealand. Nevertheless, regular runners achieve high end- $\mathrm{T}_{\text {core }}\left(>40^{\circ} \mathrm{C}\right)$ without significant symptoms of heat illness. How hard runners push themselves (perceptually) and how thermally comfortable they are best predict performance time, whilst wet- and dry-bulb temperatures best predict the risk for heat illness.

\footnotetext{
Authors' details

${ }^{1}$ School of Sport and Exercise, Massey University, New Zealand. ${ }^{2}$ Department of Health, Human Performance and Recreation, University of Arkansas, USA.

Published: 14 September 2015
} 


\section{References}

1. McKenzie R, et al: Geographical differences in erythemally-weighted UV measured at mid-latitude USDA sites. Photochem Photobiol Sci 2006, 5:343-352.

2. American College of Sports Medicine: Position Stand: Exertional heat illness during training and competition. Med Sci Sports Exerc 2007, 30:556-572.

doi:10.1186/2046-7648-4-S1-A24

Cite this article as: Mündel et al:: Summer heat stress and strain during outdoor running in Aotearoa New Zealand. Extreme Physiology \& Medicine 2015 4(Suppl 1):A24.

Submit your next manuscript to BioMed Central and take full advantage of:

- Convenient online submission

- Thorough peer review

- No space constraints or color figure charges

- Immediate publication on acceptance

- Inclusion in PubMed, CAS, Scopus and Google Scholar

- Research which is freely available for redistribution

Submit your manuscript at www.biomedcentral.com/submit
() Biomed Central 